\title{
ЗАКОНОДАВЧІ ГАРАНТІЇ СВОБОДИ СОВІСТІ
}

12 вересня 2000 року в Києві відбувся міжнародний науковопрактичний семінар "Гуманізм і демократизм законодавчих ініціатив в сфері свободи совісті: міжнародний i український контекст”, організований Міжнародною академією свободи релігій та віровизнань, Комітетом Верховної Ради України з питань культури і духовності, Відділенням релігієзнавства Інституту філософії імені Г.С. Сковороди НАН України, Центром релігійної інформації і свободи Української асоціації релігієзнавців.

В семінарі взяли участь народні депутати Верховної Ради України, науковці, державні службовці, представники релігійних організацій, журналісти. Зранку семінар працював в Інституті філософії, де були проголошені основні доповіді і повідомлення, 3 привітальним словом звернувся до учасників семінару голова Комітету Верховної Ради України з питань культури і духовності Лесь Танюк, який підкреслив важливість свободи совісті і релігійної свободи для утвердження демократичної держави, необхідність вдосконалення законодавчої та іншої нормативної бази.

У своїх виступах доповідачі, зокрема Олександр Саган (Відділення релігієзнавства Інституту філософії НАНУ) розкрив особливості моделей державно-церковних відносин, що склалися в світі; Коул Дьюрем (голова комісії ОБСС 3 релігійної свободи) охарактеризував практичний контекст законодавства 3 питань релігії в світлі міжнародних законів; Михайло Бабій зупинився на аналізі правових основ релігійного місіонерства в Україні; Валерій Климов проаналізував проекти нового Закону України про свободу совісті та релігійні організації. Різні аспекти проблеми свободи буття релігії в суспільстві розкрили С.Здіорук, В.Сленський, міжнародний досвід правового врегулювання -М.Закович, А.Колодний та ін.

В обговоренні доповідей взяли участь представники релігійних громад Г.Лозко, С.Тимченко, Л.Франчук та інші.

В другій половині дня продовжувалося обговорення проблем свободи релігій на розширеному засіданні Комітету Верховної Ради України $з$ питань культури і духовності за головуванням його голови Леся Танюка.

Змістовними були виступи А.Колодного, К.Дьюрема, Г.Удовенка, С.Пхиденка, М.Туша, Н.Марковської, М.Косіва, В.Шушкевича, Л.Танюка, які всебічно розглянули українську специфіку стану релігійної свободи, законодавчих ініціатив в цій сфері. Депутати цікавилися американським і європейським досвідом 
вирішення міжконфесійних відносин, наголошували на необхідності врахування української духовної традиції у формуванні законодавчої та нормативної бази функціонування релігії в суспільстві.

Була сформульована пропозиція про необхідність співпраці Комітету Верховної Ради 3 академічними інституціями в розробці спільних проектів 3 питань релігійної духовності, врегулювання міжконфесійних відносин і формування толерантності в українському суспільстві. 